\title{
INDEPENDENT REGULATORS: THEORY, EVIDENCE AND REFORM PROPOSALS
}

\author{
Francesc Trillas
}


The Public-Private Sector Research Center is a Research Center based at IESE Business School. Its mission is to develop research that analyses the relationships between the private and public sectors primarily in the following areas: regulation and competition, innovation, regional economy and industrial politics and health economics.

Research results are disseminated through publications, conferences and colloquia. These activities are aimed to foster cooperation between the private sector and public administrations, as well as the exchange of ideas and initiatives.

The sponsors of the SP-SP Center are the following:

- Accenture

- Ajuntament de Barcelona

- Caixa Manresa

- Cambra Oficial de Comerç, Indústria i Navegació de Barcelona

- Consell de l'Audiovisual de Catalunya

- Departament d' Economia i Finances de la Generalitat de Catalunya

- Departament d' Innovació, Universitats i Empresa de la Generalitat de Catalunya

- Diputació de Barcelona

- Endesa

- Fundació AGBAR

- Garrigues

- Mediapro

- Microsoft

- Sanofi Aventis

- ATM, FGC y TMB

The contents of this publication reflect the conclusions and findings of the individual authors, and not the opinions of the Center's sponsors. 


\title{
INDEPENDENT REGULATORS: THEORY, EVIDENCE AND REFORM PROPOSALS
}

\author{
Francesc Trillas ${ }^{1}$
}

\begin{abstract}
Regulatory independence has been proposed as a mechanism to alleviate the commitment problem associated with the sunk nature of investments in network industries. This paper summarizes the author's and others' work in this field (in a pause to take stock of several years of research) and, in addition, includes a new exercise that uses instrumental variables to endogenize both de jure and de facto regulatory independence. The institution of regulatory independence has costs as well as benefits; the positive, significant impact on industry performance is, however, most likely to be quantitatively modest. As a result of the empirical evidence and the assessment of the literature, a number of reform proposals are made to improve the institution's effectiveness.
\end{abstract}

Classification JEL: L51

Keywords: regulation, independence, strategic delegation.

${ }^{1}$ UAB and Public-Private Sector Research Center, IESE. Acknowledge to the Spanish Ministry of Science and Innovation under ECO2008-05155. 


\section{INDEPENDENT REGULATORS: THEORY, EVIDENCE AND REFORM PROPOSALS}

\section{Introduction}

Independent agencies to regulate network industries such as telecommunications, electricity or water characterized the governance mechanism of these sectors in the United States (both at the federal and state level) during the $20^{\text {th }}$ Century and up to the present. The organizational solution chosen for the web of challenges of price and entry regulation (achieving allocative and productive efficiency with commitment while avoiding capture) would have "a quasijudicial structure that applied transparent administrative procedures to establish prices, review investment and financing plans, and to specify and monitor other terms and conditions of service" (Joskow, 2007).

The United Kingdom also created independent agencies to regulate the industries that were privatized by the Thatcher governments in the 1980s. The practice started to generalize in the 1990s to many other countries.

The creation of separate regulatory agencies with a high degree of autonomy from governments has been a recommendation of institutions such as the World Bank and the IMF to Latin American and other developing countries in the context of industry and overall economic reform. As a result of this, almost all of them (with the interesting exception of Chile) created a separate regulatory institution in telecommunications and most of them in electricity. For example, Brown et al. (2006), in a book sponsored by the World Bank, claim that the independent regulator model is the most effective approach in the regulation of privatized infrastructure industries.

The European Union (EU) has also promoted the creation of National Regulatory Authorities that are independent from government. The EU directives in electricity and telecommunications oblige member states to create such authorities irrespective of countries' internal organization or institutional tradition.

Although the practice has preceded academic research, a rapidly growing literature has been developing in the recent past to bridge the gap with the literature on Central Bank Independence (CBI), which has been taken as a benchmark. As a result of early assessments of the initial experience and the growth in academic research, an "Independence Debate" has 
emerged. ${ }^{1}$ Some scholars (see, for example, Andrés et al., 2008) argue that an early interest in independence has rightly been replaced by a broader interest in regulatory governance, as reflected, for example, in Cubbin and Stern (2006) and Gutiérrez (2003). However, a focus of interest on independence is still needed, at least for two reasons: there is a theory about the specific benefits of independence (which mainly focuses on the commitment benefits of strategic delegation), which is surveyed below; and there is a persistence of international recommendations to specifically create and sustain independent regulatory agencies.

The Independence Debate in the field of network industries must be placed in the general framework of the research and debate on the role of institutions in economics: Rodrik (2007) claims that understanding the role of institutions is key to understanding economic growth, but argues that this role is complex and subtle. However, Glaeser et al. (2004) argue that policies and human capital matter more than institutions as growth factors, and criticize some of the measures of institutions that have been used in the literature. For example, they claim that the risk of expropriation is a poor proxy for a society's institutions.

This paper summarizes the author's and others' work in this field (in a pause to take stock of several years of research) and, in addition, includes a new exercise that uses instrumental variables to endogenize both de jure and de facto regulatory independence. The institution of regulatory independence has costs as well as benefits; the positive, significant impact on industry performance is, however, most likely to be quantitatively modest. As a result of the empirical evidence and the assessment of the literature, a number of reform proposals are made to improve the institution's effectiveness.

In the rest of this paper, Section 2 surveys the theoretical literature on independent regulators. Section 3 briefly summarizes the empirical literature and the evolution it has followed from simple dummy variables to continuous indices that take into account informal or de facto issues, and presents new work on the endogeneity of independence. Section 4 presents some reform proposals and concludes.

\section{The Theoretical Rationale}

\subsection{The Commitment Problem}

The regulation of network industries would be a simple technical problem if it were not for three interrelated problems (Armstrong, Cowan, and Vickers, 1994): lack of commitment (time inconsistency), asymmetric information and capture. An independent, expert regulatory commission could in theory alleviate these three problems simultaneously. Theoretical research has focused, however, on how independence alleviates the commitment problem.

The possibility that some policies were time-inconsistent was first raised by Kydland and Prescott (1977): some policies may be optimal ex post (once some agents have made their decisions), but would not have been taken ex ante if it would have been possible to influence these agents' behavior in the first place. One of the examples used by the authors was in the field of monetary policy: ${ }^{2}$ if there is a short-run trade-off between inflation and unemployment,

\footnotetext{
${ }^{1}$ See Smith (1997).

${ }^{2}$ In the original article, monetary policy is actually one of several examples of lack of credibility, the others being: the flood relief policies that should commit to not build dams and protections ex post to prevent people from moving 
a government in charge of monetary policy will have incentives to renege on past anti-inflation commitments to boost employment in the short run. This will make anti-inflation promises not credible and agents will take decisions to increase salaries and prices, thereby increasing inflation. In the regulation of a natural monopoly where a private operator has to make sunk investments, one such time-inconsistency problem appears, called the hold-up problem: once the firm has sunk the investment, a rational regulator who places enough weight on the preferences of consumers has incentives to allow the consumers use the services derived from the investments but charge a price that does not compensate for the investment cost. Once investments are sunk, a conflict emerges over the distribution of the quasi-rents. Anticipating that this will happen ex-post, the firm will be reluctant to invest ex-ante. This is also called the under-investment problem. ${ }^{3}$ The expropriation risk may manifest in more subtle forms such as unexpected quality requirements or pressures to use inefficient technologies, employment (local workers, retired politicians, or politically connected personnel) or other inputs. Underinvestment may also be more subtle than eliminating investment completely, such as reducing maintenance or using sub-optimal technologies (but ones that make less use of sunk costs).

The commitment problem in regulation is the key issue (the "overarching problem") to solve if investment in infrastructure sectors is to be made possible at all, according to some authors. This is the case of Pablo Spiller and his co-authors ${ }^{4}$ and David Newbery. ${ }^{5}$ The latter argues that different societies have solved this key issue in different forms over the last century and a half. In the United States, by using a combination of mostly private ownership and rate of return regulation with constitutional protections on a fair rate of return; and in most of the rest of the world until the last decades of the past century, by public ownership. But commitment is one issue among several, perhaps even less important than the accountability (capture) or enforcement (the risk of firm-led renegotiation of contracts) problems in Estache and Wren-Lewis (2009), or Laffont (2005). It must also be said that some of those who think that commitment is the overarching problem (such as Spiller) do not think that independent discretionary regulation, the solution explored in this paper, is necessarily the overarching solution.

There is no question that many countries have considerable unsatisfied demand and that they face major difficulties in inducing sufficient investment to meet their capacity needs. Hence, the role of the regulatory institutions is crucial in providing the credibility that will support the necessary private investment flows. Gómez-Ibáñez (2003) and Woodhouse (2006) cite the early warning by Vernon (1971) that investment by multinationals in developing countries was vulnerable to an "obsolescing bargain," by which prior to the investment the foreign firms are encouraged with all kinds of sweeteners and once the investment is sunk the firm loses bargaining power. Vernon describes the role of raw materials multinationals in developing nations, where "almost from the moment that the signatures have dried on the document,

into areas with a flood risk; investment tax-credit policies; dynamic oligopolies with a dominant firm; patent policies, and the ex post incentives of the poor to expropriate the rich (ex ante, they should prefer to commit to not expropriate them so that the rich have investment incentives and the economy grows).

${ }^{3}$ A related commitment problem in the case of asymmetric information between the regulator and the firm is that the latter may have incentives not to make enough effort or not to reveal its (efficient) type, if the regulator will require more effort in the future (this is the so-called ratchet effect, see Laffont and Tirole, 1993). In this case, the regulator may want to commit ex ante not to take advantage of information revealed by the firm.

${ }^{4}$ See for example Levy and Spiller (1994), Spiller and Guasch (1999) or Spiller and Tommasi (2007). They argue that only if the basic institutional problem of overcoming the under-investment problem is solved, one can begin to address issues such as incentives, price rules or industry structure.

${ }^{5}$ Newbery (1999). See also Noll (2000). 
powerful forces go to work that quickly render the agreements obsolete in the eyes of the government." This is consistent with the fact that expanding activities by Western multinationals in the utility sectors of developing countries in the recent decades has been very costly for the multinationals' shareholders, as documented by Trillas (2001) and Sirtaine et al. (2005).

The institutional determinants of private investment in infrastructure have been studied more closely precisely by those authors who followed the path traced by the influential contribution by Levy and Spiller (1994), which has recently been expanded by Spiller and Tommasi (2007). Credibility is linked to a country's institutional endowment. Generic laws combined with strong presidential systems, for instance, create problems of lack of credibility in many Latin American countries, among which Chile constitutes a virtuous exception, as detailed legislation sufficed to attract investment even in the absence of regulatory independence.

Work on generic microeconomic policies has highlighted the complexities of commitment problems. Bardhan (2005) points out that commitment problems may appear not only from policymakers to the private sector, but also from part of the public (the blockers) to the policymakers, by not rewarding potentially efficient policies with re-election. Commitment problems may have a "positive" side (not rewarding welfare-enhancing activities, such as investment) or a "negative" side (bailing out failing projects). Bardhan (2005) stresses the potential tensions between procedural and participatory democracy and, relatedly, the tendency in democratic unequal societies for the relatively poor majority to undermine the property rights of the rich. Inequality has been shown (for example in Easterly, 2005; Easterly et al., 2005; and Chong and Gradstein, 2005) to be negatively associated with development through its effect on hindering the build-up of high quality institutions due to political polarization, among other channels. A recent report by the Inter-American Development Bank (IABD, 2006) stresses the importance of politics in sustaining reform policies in developing countries.

Time-inconsistency problems in regulatory settings are studied in Laffont and Tirole (1993) and applied to investment incentives under complete and asymmetric information assumptions. With complete information, Salant and Woroch (1992) and Newbery (1999, ch. 2) show how optimal investment can be sustained in a reputational equilibrium provided the regulator is sufficiently far-sighted. Besanko and Spulber (1992) assume asymmetric information and abstract from the ratchet effect and focus on investment incentives in a dynamic noncommitment setting with observable investment but unobservable fixed costs. They show that under-investment can be avoided in sequential equilibrium because the firm can use its (observable) investment decision to signal its fixed cost to the regulator.

There are a few studies that analyze to what extent is regulation sustainable in the presence of sunk investments, without additional institutional restraints. Newbery (1999, ch. 2), and Salant and Woroch (1992) present two infinite horizon games of regulation that examine this issue, and hence are related to our paper. These two infinite horizon models allow the regulator (who basically represents the consumers) and a regulated firm to alleviate the underinvestment problem by sustaining a cooperative equilibrium in which the firm invests and the regulator sets a price that allows for the recovery of sunk investment costs. The structure of these games is based on the same kind of Folk Theorems that are used to explain collusion between oligopolists. This same structure, in which there is complete information, was used by Barro and Gordon (1983) to find conditions under which the inflation bias could be alleviated in an infinite horizon monetary policy game. 
One of the problems of these infinite horizon games with complete information based on the Folk Theorem is that the cooperative equilibrium is just one of many possible equilibria. In fact, the no-investment/no-recovery outcome remains a possible solution, and forms the conflict point of the game. If coordination is possible, parties would coordinate on the efficient outcome. But then the equilibrium is not 'renegotiation-proof' and this questions the credibility of trigger strategy equilibria, even though they are subgame perfect.

If we allow for asymmetric information in the form of incomplete information on the part of the firm regarding the type of regulator, then the existence of 'strong' regulators who like to commit, or are constrained by exogenous devices such as legislation to honour commitments, opens the door to reputational equilibria in which the regulator over time builds a reputation with the firm for commitment. Such theoretically sound equilibria can again sustain investment levels close to the first best. This device is technically similar to the trigger strategies and it works well (in the sense that an equilibrium can be shown to exist) in other settings such as monetary policy. However, for price regulation, Levine et al. (2005) find that such a reputational equilibrium with optimal investment may not exist if there exists a combination of a low capital depreciation rate, a low growth of consumer demand and a degree of shortsightedness on the part of the regulator. The reason for this result is that once a large investment project has been completed, the punishment for revealing oneself as a 'weak' regulator by reducing the regulated price, namely, the withdrawal of future investment, only impacts gradually over time as capital depreciates and depends on the need for more capacity to meet increasing demand. If the latter effects are small and discounting by the regulator is high, then the punishment is small and the incentive to deviate from the ex ante regulated price is high. These problems are, first, the length of the punishment phase (usually infinity) is arbitrary. There exists an infinite number of such equilibria, one for each punishment length. Even if the two players can coordinate on the best of these equilibria, there is a second more serious problem: the equilibrium is not 'renegotiation-proof'. The players always have an incentive to renegotiate (i.e., re-coordinate) after a deviation occurs, rather than carry out the punishment. This questions the credibility of trigger-strategy equilibria, even though they are sub-game perfect.

\subsection{Solutions Not Based on Delegation}

In practice, specific regulatory institutions would not be necessary if contracts between consumers (represented through voting in the democratic political process) and investors were self-enforceable, either because they were complete contracts or long term cooperation between agents could sustain cooperation. A high discount factor (agents adopting a long-term view) is one of the factors yielding cooperation. When cooperation through punishment threats or reputation cannot be sustained, either rules (in practice, a variation of complete contracts) or specific institutions are necessary to avoid the under-investment or hold-up result. Rules have the problem that they may not be robust to unforeseen contingencies. Spiller and Tommasi (2007) show that a condition for rigid rules to arise in equilibrium is that the divergence in politicians' interests concerning the issue at hand has to be more extreme than the volatility of the underlying economic and technological shocks. Utility regulation, particularly in the early years, seems to be more characterized by distributional aspects than by the importance of adaptation to technological shocks, hence the appeal of a solution based on rules. But, in practice, rule-based solutions seem to lose effectiveness after some time. Nevertheless, rule-based solutions are still seen as a way to support investment projects based on complete contracts in the Chadwick-Demsetz tradition - see Gómez-Ibáñez (2003). Another 
tradition, based on the work of Goldberg and Williamson, claims that some discretionary regulation is unavoidable, as unforeseen contingencies, bargaining and complexity require permanent institutions that reduce the transaction costs associated with private sector participation (Troesken, 2006).

"Hybrid firms" and "checks and balances" are types of solutions that provide at least partial solutions to underinvestment and are not based on a specific regulatory institution. Victor and Heller (2007) analyze the experience of five large developing countries (Brazil, China, India, Mexico and South Africa) that have undertaken a power sector reform. In all cases, they mention the political difficulties of raising tariffs to cost recovery levels as one of the main problems in attracting private investment. Interestingly, something all these countries have in common is that far from completely following the standard prescriptions of full privatization, unbundling, liberalization and independent regulation (see next sub-section below), they seem paralyzed in an ambiguous stage where hybrid firms play a pivotal role. These hybrid firms are characterized by being active political players with good connections in the corridors of power and at the same time having the professional management teams that one expects from the best international corporations.

Henisz and Zelner (2001) show how a "political constraints" index, measuring the extent of checks and balances which limit wide fluctuations in policy orientation, is strongly associated with network penetration in telecommunications and overall growth rates. The index is mainly based on a combination of veto power in independent government branches and the width of the ideological spectrum; results of the data analysis on a large set of countries and during the period 1960-1994 in Henisz and Zelner (2001) are interpreted as evidence of the importance of credible protection for investors. Increasing the number of regulators or adding veto points to government are ways to increase political constraints.

Different societies have found ways to alleviate the underinvestment problem by evolving institutions that fit well with their institutional endowment. For example, Shugart (1998) mentions the special courts and relational contracts, which, together with cultural aspects, accompanied local water concessions in France. In Chile, industry reform in the recent decades has been possible without creating independent regulatory institutions. A combination of very rigid legislation and specific simple rules have been used as commitment devices. For example, in the water sector, in the event of disagreement between government and firms, three experts (one appointed by the firm, one by government, and one by consensus) arbitrated on a rate of return; in electricity distribution, it was established that firms should earn a fixed 10\% return on investment. After some time, the Chilean system has shown signs of stress, however, as unexpected contingencies such as water droughts that impacted the mainly hydro-based electricity system, or enforcement problems in highway concessions, made it difficult to abide by the early rules. Engel et al. (2003) suggest that the concession contracts that are usually used should be complemented by variable durations, and regulatory institutions independent from those granting the initial contract, to improve commitment.

Estache and Wren-Lewis (2009) group a number of solutions to the commitment problem of discretionary regulation that are not based on delegation into industry structure solutions and contractual solutions. Industry structure solutions include more competition to minimize regulation, more vertical integration to increase investment incentives, government ownership, popular capitalism, increasing debt (this increases the minimum return that the government has to allow; however, in developing countries, debt must usually come from abroad, which may increase foreign exchange risks, increasing the probability of renegotiation). But increasing the 
weight of profits in the regulator's objective function (as many of these solutions imply) creates a different type of commitment problem which these authors call "limited enforcement:" the firm may then succeed in renegotiating initial contracts in the face of the government's opposition. Limited enforcement may reduce the ability of the government to make the firm take on risks, since the firm can renegotiate if the outcome is disadvantageous. Bidding contests may go to the firms that believe they have the highest chance of renegotiation, and not to the most efficient ones. Contract solutions include ways to avoid contractual options that increase profit volatility (such as price caps or yardstick competition), which may not be feasible with commitment difficulties. ${ }^{6}$ Increasing the periodicity of price reviews (Guthrie, 2006) or fixing ex ante an arbitration process through expert panels or international guarantees could also alleviate commitment problems.

\subsection{The Independence Solution}

Despite the wide variety, the logic and the appeal of ways to alleviate under-investment that are not based on delegation to a discretionary regulatory institution, some discretion remains necessary. There will be contingencies not contemplated in initial contracts. Some even argue that credibility may require some discretion, and not completely rigid rules, because the latter will have to be changed anyway, and it is better to have some knowledge and practice with unforeseen contingencies and discretionary decision-makers before the unforeseen contingencies cause the crisis of a well-established institution (see Cowen et al., 2000).

For industries that are organized as systems so that isolating individual lines or projects is complex, the alternative to organizing them through concession contracts (which in theory would not need a standing agency, but could be enforced by courts of justice) certainly poses difficulties.

Of course, delegation of important decisions or policy areas to agents that are not politicians and that have some degree of discretion, has many forms and is not limited to network industries regulation. ${ }^{7}$ Alesina and Tabellini (2008a and 2008b) and Maskin and Tirole (2004) distinguish between decision-makers that are motivated by re-election concerns (politicians) and decision-makers that are motivated by career or idiosyncratic concerns (bureaucrats or judges). The former are better at making decisions when the policy has far-reaching redistributive implications so that compensation of losers is important; criteria of aggregate efficiency do not easily pin down the optimal policy; and interactions across different policy domains require policy packaging or evaluating controversial trade-offs in order to build consensus or achieve efficiency. The latter are better when the electorate is poorly informed; feedback about the quality of decisions is slow so that there is a time-inconsistency problem; the majority's preferences are likely to inflict large negative externalities on the minority; the criteria for good performance can be easily described ex ante and are stable over time; the legal

\footnotetext{
${ }^{6}$ Renegotiation of contracts in network industries in Latin America and the Caribbean has been widespread (Guasch et al., 2002).

7 See Epstein and O'Halloran (1999) and De Figueiredo (2002) for delegation and policy insulation in general. See Crowe and Meade (2007) and Acemoglu et al. (2008) for recent reviews of Central Bank Independence. Blinder (1997, 1998) sees the trend towards depoliticizing agencies as seeking a balance between accountability and short-run interests, but notices that central bank insiders dismiss the focus of economists on the time-inconsistency problem. Empirical work on the strength and independence of agencies in charge of bank supervision is developed in Barth et al. (2004), Beck et al. (2006) and Caprio et al. (2007). Debrun et al. (2009) review the debate around the possibility of independent fiscal agencies.
} 
system is strong; the policy consequences touch narrowly defined interest groups. It seems clear that among all these criteria, the one that most uncontroversially fits all network industries is the presence of a time-inconsistency problem. It is more debatable whether the other criteria apply to regulation, and they will be discussed below, when some qualifications are introduced to the independence solution.

In regulation and other fields, delegation is not the only solution, as seen above. But the alternative to reputational and contract-based solutions to commitment and other problems in the infrastructure sectors and, increasingly, the preferred solution to the time-inconsistency problem, has been for governments to delegate the operation of some elements of the policy vector to authorities with powers of discretion. The theoretical case for such a policy was set out by Rogoff (1985), among others. Rogoff proposed a second-best solution to the credibility problem involving delegation to a central banker that is more inflation-averse than government. Levine et al. (2005) apply the solution to regulation and show that delegating to a regulator who is more pro-industry than a representative government equally alleviates time inconsistency. ${ }^{8}$ The solution is actually more necessary and also more difficult to achieve in regulation, because slow depreciation and slow demand growth may increase the length of the "temptation period" to renege on initial commitments, as compared with monetary policy. ${ }^{9}$ One problem is that delegation does not solve the commitment problem but rather relocates it, transforming it into a government commitment to respect regulatory independence, which some countries have found difficult (Montoya, 2007). Another problem is that it is assumed that the government can choose a regulator with the appropriate, optimally pro-industry profile, as if there was a pool of potential regulators with known track records from which to choose. Alternatively, Levine et al. (2005) suggest an interpretation which is called "as-if Rogoff delegation," by which delegation to any regulator is supplemented by statutes that oblige him or her to behave in an optimally pro-industry way. The need to appoint authorities with a high expertise in complex matters and to avoid policy polarization ${ }^{10}$ reinforces the arguments in favour of delegation.

In many cases, regulation and contracts are complementary, because i) some sort of supervision is necessary to enforce previous agreements and react to unforeseen contingencies or contract renegotiation; and ii) discretional independent regulation needs to be accompanied by mechanisms of social control, accountability, and adequate procedures, if it is to obtain social legitimacy and market credibility.

Spiller and Tommasi (2007) focus on the dilemmas between political appointees versus professional civil servants, and claim that the probability of observing independent agencies is higher in systems characterized by divided government. They argue that the use of political appointees ("including independent agencies"11) arises from the fact that in systems characterized by divided government, the executive has less control over the professional bureaucracy, as the latter will naturally tend to be aligned with the legislative powers, which

\footnotetext{
${ }^{8}$ See also Stern and Trillas (2001 and 2003).

${ }^{9}$ Another interesting difference with monetary policy is that decision making in regulation is more multi-task and less predictable than in monetary policy, as explained in an account by an academic that has also been a practitioner in both fields (see Vickers, 2002).

${ }^{10}$ See Faure-Grimaud and Martimort (2003 and 2005).

${ }^{11}$ Notice that while Alesina and Tabellini (2008b) see regulatory independence as an example of non-political decision-making, Spiller and Tommasi (2007) see them as examples of political appointment.
} 
usually last longer than their executive counterparts. They also claim that in a system of division of powers, "legislative specificity will most probably not be the norm, as legislative costs will be high and preference homogeneity among the members of the legislature will most probably be low, increasing the costs of reversing agencies and courts. It is under these circumstances where we can expect agency independence." The positive correlation between independence and divided governments remains to be tested across countries. Spiller and Tommasi (2007) also claim that in countries such as the United Kingdom with unified governments (centralized structures where the executive controls the legislative), the existence of independent agencies (whose statutes may be easily changed by a law) is not the main factor driving private investment, but rather the contract licences that provide the assurance that investments will not be expropriated. The incomplete nature of such contracts, however, is conveniently supplemented by the works of regulatory agencies with qualified staff.

An issue related to specialized regulators is the possible proximity to the industry and its interests. In new regulatory agencies, it is not unusual for a fair proportion of the staff and officials to come from the historically incumbent firm (and additionally, regulators may value future employment in the industry). However, that is precisely one of the objectives of strategic delegation: to take into account the rents of the industry. But an independent regulator must not overvalue industry rents, because that would yield too high prices, possibly coming close to monopoly prices, thereby reducing consumer welfare. In other words, there is a socially optimal level of weight that the regulator must attach to industry rents, just as there is a socially optimal level of "conservatism" in the independent central banker.

Guasch and Spiller (1999) propose recommendations (such as professional qualifications and transparency) for the criteria to be taken into account when appointing regulators to make sure that some degree of political and industry insulation is achieved. However, insulating agencies from politics may have the undesired effect of keeping alive policies that are not feasible in the medium to long run. Some political discretion that allows for well-targeted concessions to stakeholders may be useful for making short-term agreements, finding the collaboration of some agents and increasing the political legitimacy of policies. Reform policies need local politicians that can build alliances that make policies feasible on the ground. Henisz et al. (2004) emphasize that policy reforms which are not perceived as imposed from abroad, and that involve local investors, tend to benefit from higher political legitimacy than those that are seen as "foreign" solutions.

Strategic delegation has also been explored in the context of environmental regulation. Spulber and Besanko (1992) use the idea of Rogoff-delegation to develop a model where a president is shown to make credible commitments to future agency actions by choosing an agency director whose preferences regarding consumer and firm interests differ from his own. The divergence between the president's preferences and those of the desired agency director then depends on the agency's ability to make credible commitments. Spulber and Besanko point out that delegation is an imperfect mechanism because administrators are chosen before economic parameters are observed and before agency actions are taken. Boyer and Laffont (1999) analyze delegation in a regulatory setting from a different perspective. They characterize the conditions under which a biased environmental policy conducted by changing majorities who have a detailed knowledge of the economic outlook (proxied by the social cost of public funds) when they take decisions, is superior to an ex ante social welfare maximizing, but inflexible, environmental policy imposed by the constitution, drafted when that detailed knowledge was not available. 
To conclude this sub-section, it must be said that although here the independent regulator has been characterized as a discretionary, specialized, usually appointed ${ }^{12}$ entity, there is also a literature characterizing separate regulators as basically an informative agent who supplies a signal to political principals, who are the ones who make the final decisions (Laffont and Tirole, 2003; Evans et al., 2008). In practice, most regulatory agencies are both decision-making actors and suppliers of information.

\subsection{Qualifications to the Independence Solution}

Some practical problems with independent regulators have already been mentioned: the problem of knowing and choosing the person with the right preferences, and the problem of committing to respect independence. ${ }^{13}$ But even if these problems are solved, there are more substantial issues that have been raised for some time.

Bernstein (1955) provides an early criticism of the institution based on the following arguments:

- A specialized regulator raises the risk of capture, because the specialists come from the same places as the firm's managers and staff, and because they will be in a repeated relationship with firms without many other parties involved (this was formalized by Martimort, 1999). Discretion and insulation may make regulators less accountable.

- A separate regulator who sees preservation of his or her autonomy as one of his or her most important missions will be reluctant to coordinate with government, even though regulatory decisions interact with the rest of public interventions. This is usually answered by saying that regulators take day-to-day decisions on a few policy variables and policy is set by elected politicians choosing among a variety of long-run options (such as fuel decisions, ownership decisions, financing decisions). But some policies such as many on structural regulation (vertical integration, number of firms, mergers and acquisitions) affect both the long and the short run and the distinction between policy or regulation becomes blurred.

- A regulator who is insulated from the political process will lack the skills and tools to push some needed reforms through the political process, in terms of convincing public opinion, or building the necessary alliances. Politicians who anticipate that regulators will be insulated and in the job for many years will be reluctant to appoint regulators with strong political skills. Classic regulators such as Alfred Kahn in the United States and Stephen Littlechild in the United Kingdom were probably political entrepreneurs as much as good regulators, but their stature has been shown to be hard to replicate. Notice that the problem is not fixed just by having regulators who are pedagogic and spend resources educating public opinion. Sometimes, education and pedagogy are not enough; political enemies have to be defeated and the corridors of democratic politics (political parties, parliaments, executive powers, judicial arenas) have to be used so that needed reforms are passed.

\footnotetext{
12 Although a minority of state regulators in the United States are directly elected, see Besley and Coate (2003).

${ }^{13}$ Problems of regulatory capacity and inequality (fiscal capacity) put a lot of pressure on independent regulators in developing countries (Laffont, 2005, and Estache and Wren-Lewis, 2009).
} 
Other problems of independent regulators are associated with the agency costs of delegation: the agent may behave in ways that are not in the best interest of the principal (the voters, the politicians). Incentive contracts are theoretically possible (Walsh, 1995), but problematic in practice.

Alesina and Tabellini (2008b) argue that regulation of public utilities or of specific industries are examples of policies that lend themselves to bureaucratic delegation, "since they pit special interests against those of consumers as a whole, do not have large spillover effects, and policy performance can be evaluated on the basis of efficiency or other semi-technical criteria." The spillover effects and large distributional implications would make fiscal or trade policy less amenable to delegation, and the changing and vague objectives of foreign policy would make it a typical field reserved to politicians (at least, at the top of the hierarchy). However, in many cases, things are less clear-cut concerning regulation. Regulatory decisions often have important redistributive implications, especially in developing countries (Trillas and Staffiero, 2007); regulation interacts with many other policies, such as environmental policy or industrial policy; and objectives are much more multi-faceted and changing than, say, a target level of inflation in monetary policy. It is not clear either that the electorate must be poorly informed, as required by Maskin and Tirole (2004), in order to reserve a field for agents other than politicians (actually, the case can be made that the electorate is often too well-informed for commitment purposes, see Evans et al., 2008). And often, as in access pricing or crosssubsidies, it is not true that policies just pit firms against consumers, but also some firms against others and some consumers against others.

Dixit and Lambertini (2003) argue, using the example of the interaction between monetary and fiscal policy, that if there is commitment in one policy dimension (monetary policy) but not in another complementary dimension (fiscal policy), discretionary decision-makers in this complementary dimension may ruin the work of those with commitment. In some cases, if there is policy interaction between several dimensions, it may even be better to avoid committing in the first dimension, unless commitment can be achieved in the other dimension as well. This may be applicable to regulation, when the work of independent agencies interacts with interventions that are usually in the hands of politicians, such as industrial policy, fiscal policy or environmental policy (Baron, 1985). Or when the work of independent agencies in one dimension of regulation interacts with the intervention of politicians in some other dimension. ${ }^{14}$ The latter is relevant in decentralized countries when the fixed costs of specialized regulation (Mulligan and Shleifer, 2005) make it possible to create independent agencies at the national level, but not at the regional or local level. More generally, the recommendation to create national regulatory agencies with broad powers may conflict with the institutional structure of decentralized countries.

The existence of a trade-off between accountability and commitment has been observed by Estache and Wren-Lewis (2009) and Evans et al. (2008): a relatively captured regulator internalizes the firm's profits and reduces the under-investment problem. Many theoretical models (including Laffont and Tirole, 1993) see the risk of capture as concentrated in the separate regulator (in the tradition of Bernstein, 1955, mentioned above), whereas the principal is assumed to be benevolent. In practice, however, to many scholars and observers,

\footnotetext{
${ }^{14}$ In Spain, for example, electricity distribution tariffs are decided by the central government with input from the National Energy Commission, the regulatory agency, but quality levels are enforced by the local and regional authorities.
} 
independence is interpreted as introducing expert benevolence in a context of executive nonbenevolence. Foster (2005), for example, mentions that more independence is associated with less capture and with a transition from a clientelist model of regulation to a formal one. The positive political theory literature (for example, Weingast and Moran, 1983, and McCubbins et al., 1987), mostly based on the experience of the United States, sees independent regulators as appointees (the alternatives being elected regulators or civil servants) who may be as vulnerable to interest groups as politicians.

Martimort (1999) explicitly models problems that can arise when an independent regulator is captured in a setting with lump-sum transfers and no investment. In his model, the regulator and the firm interact repeatedly over time and this leads to regulatory 'drift' in the sense that it becomes increasingly difficult for Congress to design collusion-proof contracts for the firm when the degree of 'familiarity' between firm and regulator increases over time. One solution to such problems is the separation of regulatory powers between several regulators (Olsen and Torsvick, 1993; Laffont and Martimort, 1999). Here, capture is made less effective for firms because they are less able to influence the web of policies by which they are regulated. Laffont (2005) makes a powerful case for such a strategy in developing countries.

On the commitment benefits of some degree of capture, Che (1995) considers the effects of 'revolving door' arrangements, where regulators can expect employment within the regulated industry upon completion of their terms of office (see also Salant, 1995). The model assumes that regulators (not firms) make effort choices (they can improve their industry-specific knowledge) and the prospects of subsequent employment are shown to enhance these.

Of course, an idealized vision of the independent regulatory commission making reasoned decisions based on an expert assessment of all of the relevant information available often does not fully match reality, as pointed out by Joskow (2007). This author rightly argues that no regulatory agency can be completely independent of political influences. Commissioners and senior staff members are political appointments and, while they cannot be fired without just cause, they are also unlikely to be appointed or reappointed if their general policy views are not acceptable to the executive. Regulatory agencies are also subject to legislative oversight and their behavior may be constrained through the legislative budgetary process. Staffs may be underfunded and weak. Reporting requirements may not be adequate and/or the staff may have inadequate resources to properly analyze data and evaluate reports submitted by the parties to regulatory proceedings. The administrative process may be too slow and cumbersome to allow actions to be taken in a timely way. Under extreme economic conditions (such as exchange rate or financial crises), regulatory principles that evolved to protect investments in regulated enterprises from regulatory expropriation come under great stress. On the other hand, both the executive branch and the legislature may find it politically attractive to devolve complicated and controversial decisions to agencies that are both expert and arguably independent (McCubbins et al., 1987).

\section{Evidence}

Given that the commitment problem can be alleviated by regulatory independence but also by other remedies, and given that independence has both advantages and disadvantages, it is an empirical issue whether more regulatory independence is associated with better regulatory outcomes. The existing measures do not exactly test the theory, in that there is no measure of the regulator's degree of conservativeness or "pro-industryness." However, the evolution of 
independent agencies and preliminary empirical work allows some inference to be made about the correlation between the expansion of independent agencies and industry performance.

In the United States, the earliest state commissions with power over railroad rates were established by "the Granger laws" in several Midwestern states in the 1870s. The ideological roots of the expansion of these commissions can be found in the Progressive Movement (Shugart, 1998, p. 386): government institutions could have the expertise and incentives to ameliorate market imperfections. In 1887, the federal government created the Interstate Commerce Commission (ICC) to oversee and potentially regulate certain aspects of interstate railroad freight rates, though the ICC initially had limited authority and shared responsibilities with the states. The ICC's regulatory authority over railroads was expanded considerably during the first two decades of the 20th century. The ICC's responsibility was extended to telephone and telegraph (until these responsibilities were taken over by the Federal Communications Commission in 1934) and then to interstate trucking in 1935 and domestic water carriers in 1940. Federal commission regulation expanded greatly during the 1930s during the New Deal era, first with the Communications Act of 1934 and the associated creation of the Federal Communications Commission (FCC) with authority over the radio spectrum and interstate telephone and telegraph rates, and second with the expansion of the powers of the Federal Power Commission (FPC, now the Federal Energy Regulatory Commission or FERC) by the Federal Power Act of 1935 (Joskow, 2007).

Independent agencies expanded rapidly after the creation of independent regulators in the United Kingdom in the late 1980s (Stern, 2003) and with reform processes in Latin America. Since the late 1990's, the European Union obliges its member states to have independent national regulatory agencies in telecommunications and energy. Foster (2005) calls the expansion process an Anglo-Saxon export that has given way to many hybrid cases as a result of difficulties with full independence, although, as Newbery (1999) suggests, there are important differences between the United States and the United Kingdom cases, not the least being their timing. In this process, there have been successes and failures. Restricting attention to developing countries, Stern (2009, p. 31) mentions telecommunications in Philippines, and electricity in Ukraine as examples of the latter, and telecommunications in Botswana and Jamaica, Chilean water, and electricity in Uganda as examples of the former.

An early literature surveyed by Montoya (2007) developed dummy variables for the existence or otherwise of a separate agency, finding mostly but not always a positive relationship with industry performance. ${ }^{15}$ Along these lines, Estache et al. (2006) assess the effects of private capital and independent regulatory agencies on industry performance by using cross-country panel data from 1990 to 2003. In general, they find that having independent regulatory agencies positively affects affordability and labour productivity, but negatively affects quality of services.

Gutiérrez (2003) and Gual and Trillas (2004 and 2006) are the first studies to associate indices to regulatory institutions, in the spirit of the literature on Central Bank independence. Gutiérrez (2003) estimates the effect of a seven-item index of regulatory governance on mainline density and efficiency for 22 Latin American and Caribbean countries. He finds that both the index and the three main subcomponents have a positive and significant effect (at the $1 \%$ level) on mainline penetration, after controlling for competition and privatization. This holds for both static and dynamic models and the estimated coefficients are robust to corrections for potential endogeneity.

${ }^{15}$ There is also a largely descriptive literature on independent regulatory agencies developed by political scientists. See for example Gilardi (2008). 
Gual and Trillas (2004) present and use an index of regulatory independence in telecommunications for 37 countries, constructed using principal components techniques and thus taking into account the correlation between the original variables. They find that legal independence is more likely in countries with a larger incumbent and in countries with worse rule of law measures. They take this as evidence that incumbent firms lobby for independent agencies and that independence is a substitute for other ways to commit to not expropriate the incumbent's quasi-rents (see also Gual and Trillas, 2006, which as opposed to the 2004 paper, only looks at determinants and measurement, after the absence of strong results on impact of the 2004 paper). They find that independence has a positive but not significant impact on network penetration, using International Telecommunications Union data.

Cubbin and Stern (2006) use a four-component index of regulatory independence to estimate the effect of regulation on investment in electricity generation in a sample of 28 developing countries for the period 1980-2001. They estimate fixed-effects panel data models similar to those of Gutiérrez (2003). They find that the impact of a maximum index score (i.e. a regulator established by primary legislation, autonomous, funded from licence fees or similar and with freedom in setting pay) is, on average, likely to increase expected long-run per capita generation capacity levels by around $15-25 \%$. This is the predicted increase relative to an otherwise average developing country having electricity regulation conducted by a ministry without any supporting law.

Gasmi et al. (2006) use both data on overall institutional quality (what they call global accountability) and the specific regulatory institutions (local accountability) obtained from a large dataset of both developed and developing countries. They find that the positive effect of political accountability on the performance of regulation is stronger in developing countries.

Andrés et al. (2008) develop probably the most complete index of regulatory governance, based on the answers of electricity regulators to a survey with a very large number of questions. Although the effort pays off in terms of a very rich data set, its obvious disadvantage is that it is a subjective index based on the answers of interested parties. They generally find a positive impact of regulatory governance on several measures of performance in electricity distribution.

Most of these indices are mainly legal de jure indices. However, it is widely perceived that the difference between de jure and de facto independence can be large. It has already been observed above that delegation does not solve the commitment problem but rather relocates it. The independence rankings vary significantly when the regulator's political vulnerability (the ability of regulators to survive political changes) is taken into account (Montoya, 2007). A major caveat of vulnerability measures could be that leaving office after a political change is a sign of independence, as the regulator does not accept obligations from new aggressive political masters. But the rankings obtained with vulnerability are consistent with generalized views of which countries are better able to commit in practice. Staff and budgeting could be used as indicators of practice, but the agencies' workload and scope vary hugely (Foster, 2005). The importance of using de facto objective measures is illustrated by this quotation from Wright (2009) about the political dealings of the Mexican tycoon and owner of Telmex, Carlos Slim: "In March of last year, Luis Téllez, the Secretary of Communications and Transport, convened a secret meeting between Slim and President Calderón, at Los Pinos, the Mexican executive's mansion. Téllez hoped that the government and Slim could, in a statesmanship manner, work out a grand plan that would open the communications sector to increased competition; in return, the government would offer Slim something that he desperately wanted -television." Additionally one could wonder whether regulatory independence is the result of strategic 
delegation when the country is forced to do this by international institutions. This is a further reason to believe that de facto measures may be far from de jure.

There are three reasons to suspect that a variable measuring the independence of regulatory agencies may be correlated with the error term of a regression estimating the impact of independence and other variables on industry performance:

- Measurement error, both because in international comparisons we may be comparing slightly differing dimensions and because in aggregating through an index, we may assign arbitrary weights.

- Reverse causality, because a low penetration level may trigger measures to increase penetration, such as regulatory independence. Evans et al. (2008) point out that the marginal productivity of independence increases when the starting level of capital deployment is low. This pushes the sign of the correlation coefficient between investment and independence to the negative zone, whereas we would expect that more independence facilitates commitment and higher investment, pushing the same correlation coefficient to the positive zone.

- Omitted regressors, because general institutions or social preferences may at the same time be causing a high penetration level and a high level of independence. This is the Posen critique, which was developed in the case of central bank independence, but it can obviously be generalized to any type of policy delegation (see Persson and Tabellini, 2000).

To analyze the impact of independence on telecommunications performance, the general model used below can be expressed as:

$$
Y_{i t}=B_{1 i t}+B_{2} X_{2 i t}+B_{3} X_{3 i t}+\ldots X_{k i t}+\mu_{i t}
$$

where $X_{i t}=\left(X_{2 i t}, X_{3 i t}, \ldots X_{K i t}\right)$ are the explanatory variables, including an independence index taken from those developed in Montoya (2007) and control variables. $B=\left(B_{1}, B_{2}, \ldots B_{K}\right)$ are their respective parameters and $\mu_{i t}$ is an error term. We use individual fixed effects for the 23 countries.

The error term is modelled as:

$$
\mu_{i t}=\mu_{i}+v_{i t}
$$

where $\mu_{i}$ denotes non-observable individual effects and $v_{i t}$ denotes the remainder of the residual.

The performance dependent variable $Y_{i t}$ in equation (1) are fixed telephone lines for every 100 inhabitants, obtained from the International Telecommunications Union database for 23 Latin American and Caribbean countries for the period 1990-2004. I use five indices of independence:

- IR1, an eleven-component legal independence index similar to the one used in Gual and Trillas (2004). ${ }^{16}$

\footnotetext{
${ }^{16}$ Gual and Trillas (2004 and 2006) find that the correlation between the equally weighed index and the one derived from principal components analysis is above 0.9. Based on this, in the rest of this study we use equally weighted indices, although recognising that there may be some residual multicolinearity between the original variables.
} 
- PI, the index of regulators' vulnerability that varies with time presented in the previous section.

- LPI1, which multiplies IR1 and the vulnerability index at one month reported in Montoya (2007).

- LPI2, which multiplies IR1 and PI.

- LPI3, an index that adds an equally weighted sum of the eleven original components of $I R 1$ plus the vulnerability index.

Along the lines of other work in this field, it is expected that network expansion can be potentially affected by the economic structure and industry institutions. For this reason, I control for two economic structure variables: GDP measured in purchasing power parity per capita (GDPppp) and population density. I obtained those variables from the database of the World Bank, and expect that an increase in income per capita and higher density are associated with higher demand and lower costs, and therefore higher penetration, for communications and telephone services.

The starting point is a cross-section regression of average telephone penetration over the sample period for each country, to average GDP per capita and average population density. This has an adjusted $\mathrm{R}$ squared of 0.75 , both coefficients are positive and significant despite a very low number of observations (23), and the p-value associated with the $F$ test is 0 . If we add either lpi1 or ir1 as regressors to this regression, the coefficients on GDP and density keep their sign and significance. In the regression where lpil is added, the coefficient on the independence variable is negative and non-significant, whereas the adjusted $R$ squared value barely changes. However, when the irl index is added (see Table 6), this has a negative impact which is significant at the $10 \%$ level and the adjusted $\mathrm{R}$ squared improves. This negative and weakly significant result ${ }^{17}$ is very similar to that found by Gual and Trillas (2004) for a different group of 37 countries in a cross-section exercise. What Cubbin and Stern (2006) called an unsuccessful attempt to fix the endogeneity problem was due to the use of cross section: as will be seen next, once panel data are used, the relationship between independence and penetration is positive and significant, and the magnitude of the effect, although modest, increases once independence is appropriately endogenized. The cross-section exercises most probably fail to control for many country effects.

I report static panel data estimates with country fixed effects instrumenting and not instrumenting for independence (see Table 1).

In all regressions, I control for GDP per capita in purchasing power parity and for density. Both have a positive and significant impact in all regressions.

\footnotetext{
17 The negative relationship between irl and line penetration may be due to reverse causation: when line penetration is very low, the marginal productivity of independence increases and this may encourage policymakers to increase independence. This coefficient ceases to be significant when irl is instrumented by polconiii (an index of political and institutional constraints developed by Henisz and Zelner), but the Hausman test indicates that the difference between OLS and IV coefficients is not significant (although the IV coefficients are lower in magnitude, though still negative). However, with such a small sample, the usefulness of IV is very doubtful, since it has good properties only asymptotically.
} 


\section{Table 1}

Parameter estimates for main lines per 100 inhabitants. 23 countries. 1990-2004. Panel Data, country fixed effects

\begin{tabular}{|c|c|c|c|c|c|c|c|c|c|c|}
\hline Regressors & 1 & 2 & 3 & 4 & 5 & 6 & 7 & 8 & 9 & 10 \\
\hline$L P / 1$ & $6.561^{* \star *}$ & & & & & $12.307^{* \star \star}$ & & & & \\
\hline$z$ & 7.78 & & & & & 7.34 & & & & \\
\hline LPI2 & & & $2.165^{* * *}$ & & & & & $7.67^{* * *}$ & & \\
\hline$z$ & & & 4.47 & & & & & 5.93 & & \\
\hline$L P I 3$ & & & & $5.525^{\star \star \star}$ & & & & & $8.783^{\star \star *}$ & \\
\hline$z$ & & & & 7.07 & & & & & 7.39 & \\
\hline$P I$ & & & & & $.6962^{\star *}$ & & & & & $4.489^{*}$ \\
\hline$z$ & & & & & 2.28 & & & & & 1.65 \\
\hline$I R 1$ & & $5.268^{\star \star *}$ & & & $4.152^{\star \star \star}$ & & $8.997^{\star \star \star}$ & & & -.771 \\
\hline$z$ & & 6.55 & & & 4.43 & & 7.23 & & & -0.13 \\
\hline Density & $.1809^{\star * *}$ & $.113^{\star * *}$ & $.1867^{\star \star *}$ & $.1143^{* * *}$ & $.124^{* * *}$ & $.163^{\star \star *}$ & .051 & $.1502^{\star * *}$ & $.0632^{* *}$ & $.1614^{*}$ \\
\hline$z$ & 7.42 & 4.02 & 7.23 & 4.16 & 4.36 & 6.20 & 1.55 & 4.77 & 2.02 & 2.25 \\
\hline GDPpсpppr & $.0023^{* * *}$ & $.0025^{\star \star *}$ & $.0024^{\star \star *}$ & $.0025^{\star \star \star}$ & $.0023^{* * *}$ & $.0018^{\star * \star}$ & $.002^{\star \star \star}$ & $.0013^{* * *}$ & $.0022^{\star \star *}$ & $.0014^{*}$ \\
\hline$z$ & 8.51 & 9.14 & 8.21 & 9.01 & 8.32 & 5.88 & 7.82 & 3.12 & 7.75 & 2.10 \\
\hline$R$-sqr & 0.5443 & 0.5222 & 0.4897 & 0.5312 & 0.5299 & 0.4779 & 0.4899 & 0.2823 & 0.5057 & 0.2975 \\
\hline$N$-obs. & 344 & 344 & 344 & 344 & 344 & 344 & 344 & 344 & 344 & 344 \\
\hline Instruments & --- & --- & ---- & ---- & ---- & efi, staff & efi, staff & efi, staff & efi, staff & $\begin{array}{c}\text { efi, staff, polconiii } \\
\text { (weak) }\end{array}$ \\
\hline
\end{tabular}

Notes. ${ }^{*}$ statistically significant at $1 \% .{ }^{*}$ statistically significant at $5 \% .{ }^{* *}$ statistically significant at $10 \%$.

Hausman Test of Ho: † Fixed Effects vs Random Effects. ₹ The explanatory variable is not endogenous. 
As can be seen from the results, adding issues of "independence in practice" to a legal independence index changes the magnitude of the impact but not the sign or the statistical significance. In a static panel, the impact of regulatory independence on network penetration is positive and significant. When other institutional variables are added as regressors (such as reg, polconiii or checks: these are respectively a measure of overall regulatory quality obtained by the World Bank, the constraints index built by Henisz and Zelner, 2001, and an index of checks and balances also developed by the World Bank), the results for independence do not change (not reported in the table). When both an index of independence in practice (namely, the one that varies over time, PI), and an index of legal independence are included as regressors (columns 5 and 10), both have a positive and significant impact, and the impact of the legal index is higher in magnitude.

In addition to the independence indices used in table 7, when I use allphalf (an index that gives half the weight to ir1 and the other half to the vulnerability index) without instrumenting, the coefficient is 6.481195, which statistically is highly significant. In the regressions where independence is considered exogenous, the R squared is the "within" $\mathrm{R}$ squared. In the regressions where independence is endogenous, the $\mathrm{R}$ squared is the centred $\mathrm{R}$ squared, as reported by Stata.

The first 5 regressions assume that regulatory independence is exogenous. Since there is a suspicion of potential endogeneity problems in our independence measures, in columns 6-10 I endogenize the independence indices by two politico-institutional variables, efi (economic freedom index, an index developed by the Fraser Institute) and staff (a relative measure of the size of the incumbent operator). Economic freedom proxies for global accountability issues that may have a positive impact on the commitment of government to regulatory independence. There may be several reasons why incumbents favour independence:

- Laid-off personnel as a result of privatization find a job in the newly created agency, or agency staff have the expectation of finding a future job in the incumbent firm (the revolving doors phenomenon).

- Incumbents need to protect their investment in infrastructure.

In column 3, I need an additional instrument to run the overidentification test, and I use polconiii. Except in column 10, where the instruments turn out to be weak, in all the other tests the instrumental variable estimates are higher in magnitude than the estimates computed without instrumenting. Using the LPI1 index, for example, the regression results treating independence as exogenous imply that, if the model is correct, when a country has the independence level in 2004 of the highest country in the ranking (Peru), it has 4 more lines per 100 inhabitants than when it has the independence level of the lowest country in the ranking, Costa Rica, everything else being constant. However, if independence is (correctly) treated as endogenous, the impact of the difference is to have 7.6 more lines. This is not a high value in my view (and it must be considered an upper bound, as the endogenous variable is bounded and a linear model makes predictions beyond the bounds, and as we are not controlling for privatization, which is a reform usually bundled with independence), but I conclude that treating regulatory independence as exogenous may substantially underestimate the impact of independence on network penetration. However, finding good instruments is difficult, since only in the regression in column 6 were the instruments fully convincing, at least in the narrow 
sense of passing the overidentification Sargan test and a weak exogeneity test, although in all cases the null hypothesis of exogeneity was rejected using the Hausman test. ${ }^{18}$

In column 6, the Crag-Donald Wald F statistic of weak exogeneity of the instruments is 63.846, which is above the Stock-Yogo critical value at 10\% of 19.93, meaning that the hypothesis of weak exogeneity is rejected. The Sargan statistic of overidentification is 1.04 with a p-value of 0.3060 , which does not reject that the instruments are uncorrelated with the error. Finally, the chi-squared value of the Hausman test is 15.70, with an associated p-value of 0.0013, which rejects the hypothesis that there is no difference between the IV estimates and the conventional panel data estimates.

In column 7, the Crag-Donald Wald F statistic of weak exogeneity of the instruments is 125.081, which is above the Stock-Yogo critical value at $10 \%$ of 19.93 , meaning that the hypothesis of weak exogeneity is rejected. The Sargan statistic of overidentification is 3.920 with a p-value of 0.047 , which does not reject that the instruments are uncorrelated with the error, but only at the 5\% level. Finally, the chi-squared value of the Hausman test is 15.3, with an associated p-value of 0.0015 , which rejects the hypothesis that there is no difference between the IV estimates and the conventional panel data estimates.

In column 8, the Crag-Donald Wald F statistic of weak exogeneity of the instruments is 38.516, which is above the Stock-Yogo critical value at $10 \%$ of 19.93, meaning that the hypothesis of weak exogeneity is rejected. The Sargan statistic of overidentification is 4.722 with a p-value of 0.02, which does not reject that the instruments are uncorrelated with the error, but only at the $5 \%$ level. Finally, the chi-squared value of the Hausman test is 21.09 , with an associated pvalue of 0.0001 , which rejects the hypothesis that there is no difference between the IV estimates and the conventional panel data with fixed effects estimates.

In column 9, the Crag-Donald Wald F statistic of weak exogeneity of the instruments is 131.131, which is above the Stock-Yogo critical value at $10 \%$ of 19.93 , meaning that the hypothesis of weak exogeneity is rejected. The Sargan statistic of overidentification is 3.288 with a p-value of 0.0698 , which does not reject that the instruments are uncorrelated with the error, but only at the 5\% level. Finally, the chi-squared value of the Hausman test is 13.27, with an associated p-value of 0.004 , which rejects the hypothesis that there is no difference between the IV estimates and the conventional panel data with fixed effects estimates.

In column 10, the Crag-Donald Wald F statistic of weak exogeneity of the instruments is 1.931, which is below the Stock-Yogo critical value at $10 \%$ of 13.43, meaning that the hypothesis of weak exogeneity is not rejected in this case. The Sargan statistic of overidentification is 4.089 with a p-value of 0.04, which does not reject that the instruments are uncorrelated with the error, but only at the 5\% level. Finally, the chi-squared value of the Hausman test is 7.79 with an associated p-value of 0.05 , which rejects the hypothesis that there is no difference between the IV estimates and the conventional panel data with fixed effects estimates.

The data confirm that more realistic measures of independence still have a positive and significant impact on network penetration. Although the coefficients measuring legal or legal and practice independence have a different magnitude, I do not want to over-emphasize this difference at this stage, since I am aware that as with any index, the components and weights are to some extent arbitrary. It is only pointed out here that, with this preliminary analysis

\footnotetext{
${ }^{18}$ Other instruments such as reg and checks were tried, but the test results were even weaker.
} 
(which brings the empirical literature on regulation one step closer to the more advanced empirical literature on Central Bank independence), regulator independence matters but has a modest impact, even when account is taken of the problems that governments face of committing to respecting the regulator's independence.

The novelty of this exercise is that it simultaneously tackles two important problems: endogeneity and the difference between de jure and de facto. Trillas and Montoya (2008 and 2009) use some of the de facto indices also used here, but do not address in depth the endogeneity issue as is done here. The instruments used here are based on a political economy rationale, along the lines of Duso and Röller (2003), and Besley and Case (2000). Other potentially interesting instruments (such as legal origin or divided/non-divided government, which are actually the same for Latin American-Caribbean countries) cannot be used because they do not vary over time. Rank instruments have also been used in other papers such as Cubbin and Stern (2006) and Edwards and Waverman (2006), but their interpretation is unclear as the source of exogenous variation is unspecified. One strength of this exercise (as well as those in Trillas and Montoya, 2008 and 2009) is that it uses an objective measure linked to de facto independence, such as vulnerability to political changes. An advantage of objective measures (how many times has $\mathrm{X}$ happened over some time period) as opposed to subjective measures (such as expert opinions) is that they can be verified.

\section{Conclusions: Reform Proposals and Research Opportunities}

The theory of strategic delegation as applied to network industries suggests commitment (ability to reach intertemporal cooperation) and other advantages for strategically delegating to an independent regulator. The institution has also costs, deriving from imperfect coordination, agency costs of delegation, isolation from public opinion, fixed costs of regulatory specialization and risk of capture. The empirical evidence regarding the benefits of delegation in fields such as monetary policy (as summarized by Acemoglu et al., 2008) or bank supervision (as in Barth et al., 2004) is ambiguous. ${ }^{19}$ In the network industries, the empirical evidence reviewed above suggests that the impact of regulatory independence on industry performance is positive in most (although not all) cases, and it is significantly positive but modest in the original exercise presented in this paper, which improves upon early exercises by using a continuous endogenous index that takes into account de facto issues. There seems to be on balance a positive and significant impact of independence (together with other good governance attributes) on performance, although doubts remain about the magnitude of this effect.

The institution of regulatory independence does not work in isolation. It is difficult to disentangle independence from other accompanying country-specific attributes. Is it independent regulators in the United States that matters or is it the protection of a fair rate of return ${ }^{20}$ (Gilbert and

\footnotetext{
${ }^{19}$ However, independent Central Banks are seen generally as successful institutions (see for example Debrun et al., 2009), probably because they have expanded significantly in the recent past, and they have done so in very wellknown and followed jurisdictions, such as the Eurozone, the United Kingdom or Chile. Of course, there are specific examples of positive impact of independent institutions, such as in Pérez et al. (2005), on the impact of independent bank supervision on bank openness.

${ }^{20}$ Joskow (2007): "The performance of the United States institution of the independent expert regulatory agency turns on several attributes: a reasonable level of independence of the commission and its staff from the legislative and executive branches supported by detailed due process and transparency requirements included in enforceable administrative procedures, the power to specify uniform accounting rules and to require regulated firms to make their
} 
Newbery, 1994)? Is it independent regulation in the United Kingdom that matters or is it licences, courts and civil servants (Spiller and Vogelsang, 1997)?

Independent regulators are part of a complex process of power sharing. Further constraints should probably be placed on the regulators and on the executive to improve in terms of accountability, but combined with flexibility and adaptability. There is a tension between stability and efficiency, and no shortcuts to addressing the costs of independence (vertical and horizontal coordination), but there is a need for managing the expectations of consumers, investors and political stakeholders. Good institutions should not depend on who is in power, but should have some degree of flexibility. Good institutions are public goods and they need guardians. It is perhaps too early to be more specific, because except in the United States, it is a young institution.

The promise of independent regulation has to be seen in the context of the reduction in optimism vis-à-vis industry reform. As Rodrik (2007) argues, institutional functions do not map into unique institutional forms, and in this sense regulation will evolve differently in different countries. Some papers advise moderating some of the initial recommendations that surrounded reform, for example, on not using regulation for distributive purposes (Estache et al., 2001, Trillas and Staffiero, 2007). Similarly, the recommendation to create national regulatory agencies with broad responsibilities should perhaps also be moderated to create more effective institutions, addressing some of the costs and problems suggested by theory and historical evolution. ${ }^{21}$ But the institution is here to stay, both in the United States, in Latin America and other developing regions, and in Europe (where the third package of directives in telecoms and energy, if anything, strengthens the role of independent national regulatory agencies). Hence, it makes sense to think about the costs and associated trade-offs as a reason for introducing reforms in the institution that minimize the impact of such costs and trade-offs. Reforms should not necessarily "strengthen" agencies, but rather increase their effectiveness. ${ }^{22}$

Some reform proposals follow from these thoughts and the above sections:

1. Take into account the federalist dimension in the design of independent regulators: include in the agency a representation of decentralized powers, on a rotating basis if necessary, where relevant (e.g. Buenos Aires water as mentioned by Foster, 2005, ${ }^{23}$ or the Bundesbank). Monetary policy is more centralized than utilities regulation, as

books and operating records available to the commission, a professional staff with the expertise and resources necessary to analyze and evaluate this information, constitutional protections against unreasonable "takings" of investments made by regulated firms, and the opportunity to appeal regulatory decisions to an independent judiciary."

21 Joskow (2009) argues that the vulnerability of agencies to interest groups and political influence increases over time: "In my view, this has become a more serious problem over time as 'independent' regulatory agencies once heavily populated by reasonably independent technocratic experts with clear goals have increasingly come to be populated by commissioners and senior staff with narrower political goals - whether it is on the right or on the left."

22 See Borrell and Jiménez (2008) on the drivers of the effectiveness of antitrust policy. As one of these drivers, they show that it is important that an independent antitrust authority has the final say on prohibiting competition restraints. Wilks and McGowan (1995) discuss the idea of creating an independent (from the governments and the Commission) European Cartel Office, and dismiss it on the grounds that it would lose the economies of coordination with other policy goals that the Commission provides, and it would be marginalized and less effective than the Commission itself.

${ }^{23}$ Shirley (2008), however, mentions that the politicization of local and provincial representatives was one of the many and subtle causes of the institutional problems that ultimately led to the failure of the water privatization concession in Buenos Aires. 
shown in the several cases of large decentralized countries with unified monetary policy and sub-central regulation (United States, Brazil, Argentina, Australia, Canada, India). This should be reflected in more "federalist" regulatory institutions than monetary institutions.

2. Improve coordination with government and anti-trust agencies in those instances where policy interaction is more evident. This could be made through specific fora or through the direct presence, on a permanent or sporadic basis, of government representatives in the regulatory agency's organs.

3. Specify the regulatory agencies' targets and instruments, making them more transparent, and reduce discretion: give agencies less tasks, but more decision making powers based on pre-defined criteria. Separate decisions (making them not based on too generic criteria such as public interest) from other advisory roles. Debrun et al. (2009) report that one observes no independent fiscal policy agency, but one does observe fiscal policy "councils" in charge of providing objective projections and normative assessments. Should an agency that decides on access prices and market dominance be the same object as one that decides on final prices, one that decides mainly on mergers, or one that is purely advisory? Separate (through different agencies or different divisions of the same agency) the tasks of regulating for efficiency and giving subsidies, to improve the terms of the accountability/commitment trade-off (Estache and WrenLewis, 2009). Should the same agency that assesses whether a given market needs remedies be the one to administer these remedies?

4. Improve the selection of agency heads and political appointees (including where and if it ever happens, the representatives of sub-central powers). Introduce advertised selection or parliamentary hearings.

5. Introduce by law or Constitution some elements of dynamic design, such as sunset clauses, to avoid creating a self-interest for permanent regulation: Should the agency remain in existence when the number of markets that need analysis and remedies drastically diminishes, and when the main role is to oversee competition and not to administer remedies?

Future research opportunities seem promising in the following areas:

- Study the relationship between regulation and "policy" issues or other issues that interact with "regulation;"

- Examine the regulatory role of courts and the judiciary;

- Explore more sophisticated ways of measuring de facto independence: additional variables (budgets, staff), use of social network analysis, fuzzy sets analysis. ${ }^{24}$ Although it is not possible to have perfect measures, work should continue on the challenges of measurement and empirical identification.

- Investigate the relationship between regulation, on the one hand, and ownership and finance issues, on the other hand.

\footnotetext{
${ }^{24}$ See some preliminary work along these lines in Maggetti (2005 and 2007).
} 
- The determinants of the ability to create and sustain independent regulatory agencies should be probed further: size of the polity (related to the fixed costs of regulatory specialization), development level, institutional development (courts, contracts), legal tradition.

- A shortcoming of existing models of independent regulation is that they are framed in a monopolistic context, whereas many regulators (at least in telecoms and electricity, where separate regulators are most prevalent) oversee at least partially liberalized industries. Edwards and Waverman (2006) is an exception. 


\section{References}

Acemoglu, D., Johnson, S., Querubín, P., and Robinson, J.A. (2008), "When Does Policy Reform Work? The Case of Central Bank Independence," Brookings Papers on Economic Activity, Spring, pp. 351-417.

Alesina, A., Tabellini, G. (2008a), "Bureaucrats or Politicians? Part I: A Single Policy Task,“ American Economic Review, 97, pp. 169-179.

Alesina, A., Tabellini, G. (2008b), "Bureaucrats or Politicians? Part II: Multiple Policy Tasks," Journal of Public Economics, 92, pp. 426-447.

Andrés, L., Guasch, J.L., and Azumendi, S.L. (2008), "Regulatory Governance And Sector Performance: Methodology And Evaluation For Electricity Distribution In Latin America,” WB Policy Research Working Paper 4494.

Armstrong, M., Cowan, S., and Vickers, J. (1994), "Regulatory Reform: Economic Analysis and British Experience," The MIT Press.

Bardhan, P. (2005), "Scarcity, Conflicts, and Cooperation. Essays in the Political and Institutional Economics of Development,” The MIT Press.

Baron, D.P. (1985), “Non-cooperative Regulation of a Non-localized Externality," Rand Journal of Economics, 16(4), pp. 553-568.

Barro, R., Gordon, D.B. (1983), "Rules, discretion and reputation in a model of monetary policy," Journal of Monetary Economics, 12, pp.101-120.

Barth, J.R., Caprio, G., and Levine, R. (2004), "Bank Regulation and Supervision: What Works Best,” Journal of Financial Intermediation, 13, pp. 205-248.

Beck, T., Demirgüç-Kunt, A., and Levine, R. (2006), "Bank Supervision and Corruption in Lending," Journal of Monetary Economics, 53, pp. 2131-2163.

Bernstein, M. (1955), "Regulating Business by Independent Commission,” Princeton University Press.

Besanko, D., Spulber, D. F. (1992), "Sequential Equilibrium Investment By Regulated Firms," Rand Journal of Economics, 23(2), pp. 153-170.

Besley, T., Case, A. (2000), "Unnatural Experiments? Estimating the Incidence of Endogenous Policies,” Economic Journal, 110(467), pp. F672-F694.

Besley, T., Coate, S. (2003), "Elected versus Appointed Regulators: Theory and Evidence," Journal of the European Economic Association, 1(5), pp. 1176-1206.

Blinder, A. (1997), “Is Government Too Political?,” Foreign Affairs, 76(6), pp. 115-126.

Blinder, A. (1998), “Central Banking in Theory and in Practice,” The MIT Press.

Borrell, J.J., Jiménez, J.L. (2008), "The Drivers of Antitrust Effectiveness," Hacienda Pública Española/Revista de Economía Pública, 185(2), pp. 69-88.

Boyer, M., Laffont, J.-J., (1999), "Toward a political theory of the emergence of environmental incentive regulation,” Rand Journal of Economics, 30 (1), pp. 137-157. 
Brown, A.C., Stern, J., and Tenenbaum, B. (2006), "Handbook for Evaluating Infrastructure Regulatory Systems," The World Bank.

Caprio, G., Laeven, L., and Levine, R. (2007), “Governance and Bank Valuation,” Journal of Financial Intermediation, 16, pp. 584-617.

Che, Y.-K. (1995), "Revolving Doors And The Optimal Tolerance For Agency Collusion," Rand Journal of Economics, 26(3), pp. 378-397.

Chong, A., Gradstein, M. (2004), "Inequality and Institutions," Inter-American Development Bank Working Paper \#506.

Cowen, T., Glazer, A., and Zajc, K. (2000), “Credibility May Require Discretion, Not Rules," Journal of Public Economics, 76(2), pp. 295-306.

Crowe, C., Meade, E.E. (2007), "The Evolution of Central Bank Governance around the World," Journal of Economic Perspectives, 21(4), pp. 69-90.

Cubbin, J., Stern, J. (2006), "The Impact of Regulatory Governance and Privatization on Electricity Industry Generation Capacity in Developing Economies," The World Bank Economic Review, 20(1), pp. 115-141.

Debrun, X., Hauner, D., and Kumar, M.S. (2009), "Independent Fiscal Agencies," Journal of Economic Surveys, 23(1), pp. 44-81.

de Figueiredo, Jr., R. (2002), "Electoral Competition, Political Uncertainty and Policy Insulation,” American Political Science Review, 96(2), pp. 321-333.

Dixit, A., Lambertini, L. (2003), "Interactions of Commitment and Discretion in Monetary and Fiscal Policies,” American Economic Review, 93(5), pp. 1522-1542.

Duso, T., Röller, L.-H. (2003), "Endogenous Deregulation. Evidence from OECD Countries," Economic Letters, 81(1), pp. 67-71.

Easterly, W. (2005), “Inequality Does Cause Underdevelopment,” mimeo.

Easterly, W., Ritzen, J., and Woolcock, M. (2005), "Social Cohesion, Institutions, and Growth,” mimeo.

Edwards, G., Waverman, L. (2006), "The Effects of Public Ownership and Regulatory Independence on Regulatory Outcomes: A Study of Interconnect Rates in EU Telecommunications," Journal of Regulatory Economics 29(1), pp. 23-67.

Engel, E., Fischer, R., and Galetovic, A. (2003), "Privatizing Highways in Latin America: Fixing What Went Wrong," Economia: Journal of the Latin American and Caribbean Economic Association, 4(1), pp. 129-158.

Epstein, D., O’Halloran, S. (1999), “Delegating Powers: A Transaction Cost Politics Approach to Policy Making under Separate Powers,” Cambridge University Press.

Estache, A., Gómez-Lobo, A., and Leipzigger, D. (2001), "Utilities Privatization and the Poor: Lessons and Evidence from Latin America,” World Development, 29(7), pp. 1179-1198.

Estache, A., Goicoechea, A., and Manacorda, M. (2006b), “Telecommunications Performance, Reforms and Governance," mimeo. 
Estache, A., Wren-Lewis (2009), "Towards a Theory of Regulation for Developing Countries: Following Jean-Jacques Laffont's Lead,” Journal of Economic Literature, forthcoming.

Evans, J., Levine, P., and Trillas, F. (2008), "Lobbies, Delegation and the Underinvestment Problem in Regulation," International Journal of Industrial Organization, 26(1), pp. 17-40.

Faure-Grimaud, A., Martimort, D. (2003), "Regulatory Inertia," Rand Journal of Economics, 34(3), pp. 413-437.

Faure-Grimaud, A., Martimort, D. (2005), "Political Stabilisation by an Independent Regulator, bookchapter in Vivek Ghosal and Johan Stennek," (eds.), "The Political Economy of Antitrust," Chapter 15, Elsevier Publishers.

Foster, V. (2005), "Ten Years of Water Service Reform in Latin America, Toward an AngloFrench Model,” Water Supply and Sanitation Sector Board Discussion Paper Series, 3.

Gasmi, F., Noumba, P., and Recuero Virto, L. (2006), "Political Accountability and Regulatory Performance in Infrastructure Industries: An Empirical Analysis,” World Bank Policy Research Working Paper, 4101.

Gilardi, F. (2008), "Delegation in the Regulatory State: Independent Regulatory Agencies in Western Europe,” Edward Elgar.

Gilbert, R., Newbery, D. (1994), “The Dynamic Efficiency of Regulatory Constitutions," Rand Journal of Economics, 25(4), pp. 538-554.

Glaeser, E.L., Laporta, F., López-de-Silanes, F., and Shleifer, A. (2004), "Do Institutions Cause Growth?," Journal of Economic Growth, 9, pp. 271-301.

Gómez-Ibáñez, J.A. (2003), "Regulating Infrastructure. Monopoly, Contracts and Discretion,” Harvard University Press.

Gual, J., Trillas, F. (2004), “Telecommunications Policies: Determinants and Impact,” CEPR Discussion Paper 4578.

Gual, J., Trillas, F. (2006), "Telecommunications Policies: Measurement and Determinants," Review of Network Economics, 5(2), pp. 249-272.

Guasch, J.L., Spiller, P. (1999), “Regulatory Reform in Latin America and the Caribbean,” World Bank.

Guasch, J.L., Laffont, J.J., and S. Straub (2002), "Renegotiations of concession contracts in Latin America," World Bank Policy Research Working Paper 3011.

Guthrie, G. (2006), "Regulating Infrastructure: The Impact on Risk and Investment," Journal of Economic Literature, 44, pp. 925-972.

Gutiérrez, L. (2003), "The Effect of Endogenous Regulation on Telecommunications Expansion and Efficiency in Latin America," Journal of Regulatory Economics, 23(3), pp. 257-268.

Henisz, W.J., Zelner, B.A. (2001), "The Institutional Environment for Telecommunications Investment," Journal of Economics and Management Strategy, 10, pp. 123-147. 
Henisz, W., Zelner, B., and Guillén, M. (2004), “International Coercion, Emulation and Policy Diffusion: Market Oriented Infrastructure Reforms, 1977-99”, William Davidson Institute Working Paper Number 713.

IADB (2006), "The Politics of Policies: Economic and Social Policies in Latin America," InterAmerican Development Bank and David Rockefeller Centre for Latin American Studies, Harvard University.

Joskow, P. (2007), "Regulation of Natural Monopolies," in A. Mitchell Polinsky and Steven Shavell (eds)," "Handbook of Law and Economics."

Joskow, P. (2009), "Deregulation,” Distinguished Lecture, AEI Center for Regulatory and Market Studies.

Kydland, F.E., Prescott, E. (1977), "Rules rather than Discretion: The Inconsistency of Optimal Plans,” Journal of Political Economy, 85, pp. 473-491.

Laffont, J.J. (2005), “Regulation and Development,” MIT Press, Cambridge MA.

Laffont, J.J., Martimort, D. (1999), "Separation of Regulators Against Collusive Behaviour," Rand Journal of Economics, 30(2), pp. 232-262.

Laffont, J.J., Tirole, J. (1993), “A Theory of Incentives in Procurement and Regulation,” The MIT Press.

Levine, P., Stern, J., and Trillas, F. (2005), "Utility Price Regulation and Time Inconsistency: Comparisons with Monetary Policy,” Oxford Economic Papers 57, pp. 447-478.

Levy, B., Spiller, P. T. (1994), "The Institutional Foundations of Regulatory Commitment: A Comparative Analysis of Telecommunications Regulation," Journal of Law, Economics and Organisation, 10(2), pp. 201-246.

Maggetti, M. (2005), “Towards a Framework to Assess the Informal Independence of Regulatory Agencies. Early Investigations,” mimeo.

Maggetti, M. (2007), “De Facto Independence after Delegation: A Fuzzy-Set Analysis,” Regulation and Governance, 1, pp. 271-294.

Martimort, D. (1999), "The Life Cycle Of Regulatory Agencies: Dynamic Capture And Transaction Costs," Review of Economic Studies, 66, pp. 929-947.

Maskin, E., Tirole, J. (2004), "The Politician and the Judge: Accountability in Government," American Economic Review, 94(4), pp. 1034-1054.

McCubbins, M.D., Noll, R.G., and Weingast, B.R. (1987), “Administrative Procedures as Instruments of Corporate Control," Journal of Law, Economics and Organization, 3, pp. 243-277.

Montoya, M.A. (2007), “Independencia y Compromiso en la Regulación de las Telecomunicaciones," $\mathrm{PhD}$ thesis, Universitat Autònoma de Barcelona.

Mulligan, C.B., Shleifer, A. (2005), "The Extent of the Market and the Supply of Regulation," The Quarterly Journal of Economics, November, pp. 1445-1473.

Newbery, D. M. (1999), "Privatisation, Restructuring and Regulation of Network Utilities," MIT Press, Cambridge, Mass. 
Noll, R. (2000), "Telecommunications Reform in Developing Countries," in Anne Krueger (ed.), "Economic Policy Reform: The Second Stage," University of Chicago.

Olsen, T., Torsvick, G. (1993), "The Ratchet Effect in Common Agency: Implication for Privatisation and Regulation," Journal of Law, Economics and Organisation, 9, pp. 136-158.

Pérez, D., Salas Fumás, V., and Saurina, J. (2005), "Banking Integration in Europe," Moneda y Crédito: Revista de Economía, 220, pp. 105-144.

Persson, T., Tabellini, G. (2000), “Political Economics,” The MIT Press.

Rodrik, D. (2007), "One Economics, Many Recipes: Globalization, Institutions and Economic Growth," Princeton University Press.

Rogoff, K. (1985), "Optimal Commitment to an Intermediate Monetary Target," Quarterly Journal of Economics, 100, pp. 1169-1189.

Salant, D.J. (1995), "Behind The Revolving Door: A New View Of Public Utility Regulation," Rand Journal of Economics, 26(3), pp. 362-377.

Salant, D.J. and Woroch, G. (1992), "Trigger Price Regulation," Rand Journal of Economics, 23, pp. 29-51.

Shirley, M.M. (2008), “Institutions and Development,” Edward Elgar.

Shugart, C.T. (1998), "Regulation-by-Contract and Municipal Services: The Problem of Contractual Incompleteness,” PhD. Thesis, Harvard University.

Sirtaine, S., Pinglo, M.E., Guasch, J.L., and Foster, V. (2005), "How Profitable Are Private Infrastructure Concessions in Latin America? Empirical Evidence and Regulatory Implications,“ The Quarterly Review of Economics and Finance, 45 (2-3), pp. 380-402.

Smith, W. (1997), “Utility Regulators -The Independence Debate," Public Policy for the Private Sector Note, 127, World Bank.

Spiller, P., Vogelsang, I. (1997), "The Institutional Foundations of Regulatory Commitment in the UK: The Case of Telecommunications," Journal of Institutional and Theoretical Economics, 153(4), pp. 607-629.

Spiller, P., Tommasi, M. (2007), "The Institutions of Regulation. An Application to Public Utilities," in "Handbook of New Institutional Economics," Springer.

Spulber, D.F., Besanko, D. (1992), "Delegation, Commitment And The Regulatory Mandate," Journal of Law, Economics and Organisation, 8(1).

Stern, J. (2003), "What the The Littlechild Report Actually Said," Regulation Initiative Working Paper, 55.

Stern, J. (2009), “The Regulatory and Institutional Dimension of Infrastructure Services," CCRP Working Paper, 15.

Stern, J., Trillas, F. (2001), "Regulation of Telecommunications: What Works and Why? Lessons from Independent Central Banks,” Business Strategy Review, 12(4), pp. 17-28. 
Stern, J., Trillas, F. (2003), "Independence and Discretion in Telecommunications Regulation: Lessons from Independent Central Banks," Utilities Policy, 11, 2003, pp. 191-201.

Trillas, F. (2001), “The Takeover of Enersis: The Control of Privatized Utilities," Utilities Policy, 10, pp. 25-45.

Trillas, F., Montoya, M.A. (2008), "The Degree of Commitment to Regulator Independence: Measurement and Impact," Hacienda Pública Española. Revista de Economía Pública, 185(2), pp. 89-114.

Trillas, F., Montoya, M.A. (2009), "The Measurement of Regulator Independence in Practice: Latin America and the Caribbean," International Journal of Public Policy, 4(1/2), pp. 113-134.

Trillas, F., Staffiero, G. (2007), "Regulatory Reform, Development and Distributive Concerns," SP-SP Center Working Paper, 665, IESE Business School.

Troesken, W. (1996), "Why Regulate Utilities? The New Institutional Economics and the Chicago Gas Industry,” The University of Michigan Press.

Vernon, R. (1971), “Sovereignty at Bay: The Multinational Spread of U.S. Enterprises,” Basic Books.

Vickers, J. (2002), “The Hedgehog and the Fox in Economic Policy,” Oxford Business Alumni Lecture.

Victor, D.G., Heller, T.C. (2007), "The Political Economy Of Power Sector Reform: The Experiences Of Five Major Developing Countries," Cambridge University Press.

Voigt, S., Salzberger, E.M. (2003), "Choosing Not to Choose: When Politicians Choose to Delegate Powers,” Kyklos, 55(2), pp. 289-310.

Walsh, C. (1995), “Optimal Contracts for Independent Central Bankers," American Economic Review, 85, pp. 150-167.

Weingast, B.R., Moran, M.J. (1983), "Bureaucratic Discretion or Congressional Control? Regulatory Policymaking at the Federal Trade Commission," Journal of Political Economy, 91, pp. 765-780.

Wilks, S., McGowan, L. (1995), "Disarming the Commission: The Debate over a European Cartel Office,” Journal of Common Market Studies, 32(2), pp. 259-273.

Woodhouse, E.J. (2006), "The Obsolescing Bargain Redux? Foreign Investment in the Electric Power Sector in Developing Countries," International Law and Politics, 38, pp. 121-219.

Wright, L. (2009), “Slim's Time,” The New Yorker, June 1. 